Tjalling C. Koopmans Research Institute Trlligh Koopmen

Discussion Paper Series nr: 11-15

\title{
Real Pension Rights as a Control Mechanism for Pension Fund Solvency
}

Jacob A. Bikker Thijs Knaap

Ward E. Romp 


\section{Tjalling C. Koopmans Research Institute Utrecht School of Economics Utrecht University}

Kriekenpitplein 21-22

3584 TC Utrecht

The Netherlands

telephone $\quad+31302539800$

fax +31302537373

website www.koopmansinstitute.uu.nl

The Tjalling C. Koopmans Institute is the research institute and research school of Utrecht School of Economics.

It was founded in 2003, and named after Professor Tjalling C. Koopmans, Dutch-born Nobel Prize laureate in economics of 1975.

In the discussion papers series the Koopmans Institute publishes results of ongoing research for early dissemination of research results, and to enhance discussion with colleagues.

Please send any comments and suggestions on the Koopmans institute, or this series to J.M.vanDort@uu.nl

ontwerp voorblad: WRIK Utrecht

\section{How to reach the authors}

Please direct all correspondence to the last author at the underlined address.

\section{Jacob A. Bikker}

De Nederlandsche Bank

Netspar

Utrecht University School of Economics

P.O. Box 80125

3508 TC Utrecht

The Netherlands

Thijs Knaap

CPB

University of Amsterdam

Netspar

Ward E. Romp

University of Amsterdam

Faculty of Economics and Business

Valckeniersstraat 65-67

1018 XE Amsterdam

The Netherlands

Tinbergen Institute

Netspar

CPB

E-mail: w.e.romp@uva.nl 
Utrecht School of Economics

Tjalling C. Koopmans Research Institute

Discussion Paper Series 11-15

\title{
Real Pension Rights as a Control Mechanism for Pension Fund Solvency
}

\author{
Jacob A. Bikkera \\ Thijs Knaap \\ Ward E. Romp \\ ${ }^{a}$ De Nederlandsche Bank \\ Utrecht University \\ Netspar \\ ${ }^{\mathrm{b}} \mathrm{CPB}$ \\ University of Amsterdam \\ Netspar \\ 'University of Amsterdam \\ Tinbergen Institute \\ Netspar \\ $C P B$
}

August 2011

\begin{abstract}
This paper models policy responses to changes in solvency by Dutch occupational pension funds using a unique panel dataset containing the balance sheets of all registered pension funds in the Netherlands over a period of 15 years (1993-2007). The model describes how nominal pension rights are expanded, by e.g. indexation or backservice, or, on the contrary, how the current pension accumulation is skimmed, e.g. by setting the pension premium over its actuarially fair price to build buffers. Policy responses are explained by the funding ratio and other pension fund characteristics such as pension funds' size and type, and participants' ages. We find that pension rights are expanded in line with the funding ratio, but that the pension funds' response function exhibits two sharp and significant behavioural breaks, close to the minimum funding ratio of $105 \%$ and the target ratio of around $125 \%$. These levels also play a pivotal role in current supervisory regulation. We further find that large pension funds and grey funds are relatively generous to participants.
\end{abstract}

Keywords: pension funds, pension rights, risk sharing instruments, indexation, funding ratio, solvability, regime shifts.

JEL classification: G23, G28

\section{Acknowledgements}

The authors are grateful to Dirk Broeders and Paul Cavelaars, and participants of the 15 November 2010 Netspar conference in Maastricht, and the DNB research seminar (27 January 2011). The views expressed in this paper are personal and do not necessarily reflect those of CPB or DNB.

At the time of writing this paper, Thijs Knaap worked at CPB Netherlands Bureau for Economic Policy Analysis, The Hague. 


\section{Introduction}

The Dutch pension sector is large with 514 registered pension funds (at end-2010), controlling an invested wealth of more than 746 billion euro, that is, $126 \%$ of the Dutch GDP. This population of pension funds is very heterogeneous in terms of size. The largest fund, $A B P$, has about 2.8 million participants and controls 208 billion euro (ABP, 2010), whereas some small pension funds have fewer than 10 participants.

Depending on the type of contract, all pension funds face uncertainties with respect to their benefits, stemming from the rate of return on their assets, the mortality rate of their participants, the inflation rate, wage growth and, in the Netherlands since 2007, the market-based interest rate term structure for discounting. If the value of the pension funds' assets declines relative to the current value of their liabilities, pension fund boards can use different instruments to reduce the gap. In case of a funding shortfall, the board can add a surcharge to the pension premium, suspend indexation to wage or price inflation or adjust the asset mix to limit further downside risks. As a final measure, a pension fund board may cut accrued benefits. Financial support from the associated company, if one exists, requires the permission of this 'sponsor', as such action is rarely or never enforceable. When a pension fund's assets exceed liabilities comfortably, the fund can provide indexation, raise benefits or lower pension premiums, or the sponsor may receive part of the excess return as a reverse financial support, something which happened regularly in the 1990s.

Despite the size of the Dutch pension sector and its impact on the economy, relatively little is known about the use pension funds make of these risk sharing instruments. To fill this gap is the primary objective of this paper. Specifically, we wish to investigate how the average Dutch pension fund's policy plan responds to changes in its solvability. A second research question is whether a predictable relationship exists between known properties of the pension fund - such as its age structure, its size, and the presence of an external sponsor - and the way it handles solvency problems.

To assess how the solvency governance of a pension fund is conducted in practice, we use a unique dataset from the Dutch central bank ('DNB') which supervises pension funds in the Netherlands. Every pension fund has to submit yearly and quarterly reports to DNB, in which it outlines its financial position. The more detailed yearly reports constitute our dataset, together with balance sheets of all registered pension funds in the Netherlands for the 1993 to 2007 period, 15 years in total. They do not, however, specify the actual use of such risk sharing instruments as are listed above. The dataset has been used earlier by Bikker, Broeders, Hollanders \& Ponds (2011) in a study on the asset allocation of pension funds. These authors show that the type of assets held is correlated significantly with the age of the fund's active participants. Bikker, Broeders \& De Dreu (2010) and De Dreu \& Bikker (2009) use a quarterly version of this dataset to argue that the 
asset management of large pension funds is markedly different from that of small pension funds, which may apply less sophisticated risk management.

We use the reported financial and miscellaneous data to investigate the relationship between the assets and the liabilities of pension funds. This allows us to estimate whether changes in a fund's funding ratio are absorbed by its buffers or by additional participants' pension rights. We condition these policy actions on time and on the pension fund's characteristics. As expected, we find a positive relation between the funding ratio and the generosity of the pension fund, in terms of granting new pension rights. However, our main finding is the existence of a strong nonlinearity in pension funds' policy response to their funding ratio. When the ratio falls below $105 \%$, pension fund participants - active workers, inactive participants and retirees - see their rights promptly impaired by, e.g., withheld indexation. Secondly, we observe that the pension fund's average age of participants and number of retirees correlate positively with its generosity. Lack of data prevents us from determining whether this is due to pressure from the older participant through labour unions to increase benefits or to avoid reductions in indexation, or to other reasons. We also find that larger funds are more generous - possibly the benefit of returns to scale. Finally, company pension funds are observed to be, on average, more generous compared to industry-wide funds, ascribed to the sponsor relations of the former.

The rest of this paper is organized as follows: Section 2 explains the Dutch occupational pension system. Section 3 introduces the dataset and our method for recovering pension policy from the available data. Section 4 then specifies the models used to describe the impact of the pension funds' solvability and their policy responses, and presents estimation results. Section 5 concludes.

\section{The Dutch occupational pension system}

As in most developed countries, the institutional structure of the pension system in the Netherlands is organized as a three-pillar system. The first pillar comprises the public pension scheme, financed on a pay-as-you-go base. It offers a basic flat-rate pension to all Dutch inhabitants above the age of 65 . The benefit level is linked to the statutory minimum wage. The second pillar consists of fully funded 'supplementary' pension schemes managed by pension funds. The third pillar comprises tax-deferred personal savings, which individuals undertake on their own initiative.

The Dutch pension system is unique as regards the relative size of the second pillar. It covers 94 percent of all employees. The value of assets under management at the end of 2010 amounted to 746 billion euro, or 126 percent of the Dutch GDP. More than 85 percent of all pension funds are of the company pension fund type. Of the remaining 15 percent, most are industry-wide funds. Participation in industry-wide pension funds is (under certain conditions) mandatory for all 
employers in a particular sector. An employer can opt out only if it establishes a company pension fund that offers a better pension plan to its employees than the industry-wide fund. The circa 95 industry-wide pension funds are the dominant players, both in terms of active participants (market share above $85 \%$ ) and in assets under management (over 70\%). In 2007, almost 600 company pension funds encompassed over a quarter of the assets, serving 12 percent of plan participants. A small number of generally small professional group pension funds form the third type of pension funds, organized for a specific group of professionals such as physicians or notaries.

Bovenberg et al. (2007) present several reasons for the existence of the funded pension schemes, explaining the services they provide in excess of what individuals can organize themselves. The pension funds act as cost efficient asset managers, allow young people to leverage their human capital, enable intergenerational risk-sharing and provide non-traded quasi-assets. In addition, they may fulfil a paternal role for participants with myopic tendencies, in that workers cannot opt out of the fund associated with their employer, industry sector or profession.

The supplementary or occupational pension system in the Netherlands, the subject of this paper, is organized mainly in the form of funded defined benefit (DB) plans. The benefit entitlement is determined by years of service and a reference wage, which may be final pay (as during most years of our sample) or the average wage over the years of service, as is nowadays most common. As corporate sponsors do not have a legal obligation to cover shortfalls in the respective company's pension fund, the residual risk is borne by the participants themselves. ${ }^{1}$ Obviously, the same applies to participants in other types of pension funds. This type of plan may also be labelled as hybrid rather than $\mathrm{DB}$, since it has both defined benefit and defined contribution traits. It is partly DB by nature, in that the yearly accrual of pension rights is specified in the same way as in a traditional DB plan, but at the same time it has defined contribution (DC) features, in that the yearly indexation to price or wage inflation is linked to the financial position of the fund and, therefore, to its investment returns.

The defined benefit formula takes the public - first pillar - scheme into account. Shocks in investment returns are first absorbed by the pension fund buffer, next DB pension funds adjust pension contributions and indexation of accrued benefits as instruments to restore the funding ratio. Whereas higher contributions weigh on active participants, lower indexation hurts older participants most. ${ }^{2}$ The less flexible these instruments are, the longer it takes to adjust the funding ratio, and the more strongly will shocks be borne by active participants and shared with future participants.

\footnotetext{
${ }^{1}$ Although there is no legal obligation, a corporation may experience a moral obligation to participate in sharing the losses of its pension fund. Where the corporation adopts this role, we refer to it as the sponsor of the plan. Also note that the Netherlands has no pension guarantee fund as opposed to e.g. the US, the UK and Germany.

${ }^{2}$ In an average wage defined benefit scheme, the accrued pension rights of active participants are often also subject to conditional indexation.
} 


\section{The data}

Each year, a pension fund must report an extensive, prescribed set of variables to DNB, which exercises supervision on the sector. ${ }^{3}$ The number of pension funds declined during the period under our observation. The solid line in Figure 1 shows the decline from over 1,000 funds in 1993 to 623 in 2007. The main cause of this decline is a process of mergers and liquidations, possibly driven by increasing regulatory demands on pension funds and unused scale economies (see Bikker \& De Dreu, 2009; Bikker, Steenbeek \& Torracchi, 2011).

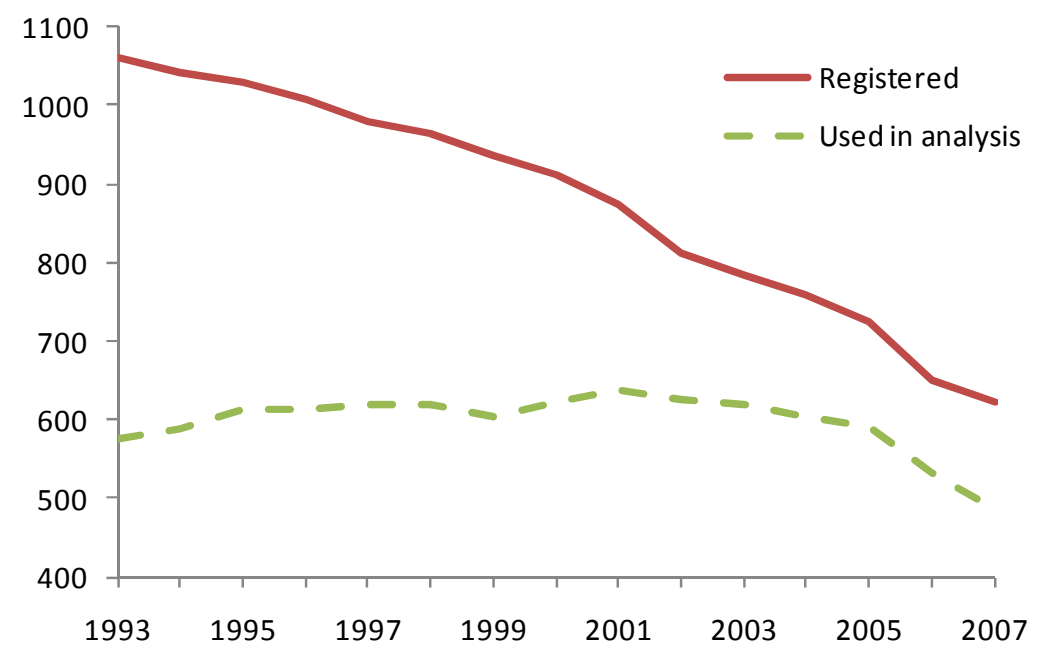

Figure 1: The number of pension funds in the dataset and the number of funds actually used in the analysis per year.

This paper uses a subset of the available data, comprising pension funds with at least 150 participants. We exclude smaller funds because many of them are tax vehicles for e.g. company owner-managers, and their small size may limit their capacity to pursue solvency policies. Excluding smaller funds eliminates almost half the sample in 1993. As Figure 1 shows, consolidation and liquidation reduced the number of excluded funds over time. The number of funds included in our analysis rose initially, and in the final year of our sample, close to $80 \%$ of the registered funds met our selection criterion.

\footnotetext{
${ }^{3}$ Until 2004, pension funds had to report to the 'Pensioen- en Verzekeringskamer'. This supervisor merged with the Dutch central bank in 2004. The anonymised data used for this research were obtained from De Nederlandsche Bank in cooperation with Statistics Netherlands, subject to DNB's disclosure policies, see http://www.dnb.nl/en/statistics/statistische-microdata/index.jsp. Anonymisation makes it impossible to link the dataset to data available from other sources like pension funds' annual reports and websites. The interpretation of the data are solely the responsibility of the authors.
} 


\begin{tabular}{rrrrrrr}
\hline \multicolumn{7}{c}{ Size classes based on number of participants } \\
\hline Year & $150-500$ & $500-1 k$ & $1 k-10 k$ & $10 k-100 k$ & $100 k+$ & Total \\
\hline 1993 & 163 & 103 & 220 & 74 & 16 & 576 \\
1994 & 173 & 105 & 219 & 76 & 15 & 588 \\
1995 & 186 & 114 & 222 & 74 & 17 & 613 \\
1996 & 172 & 117 & 234 & 74 & 17 & 614 \\
1997 & 171 & 115 & 240 & 74 & 18 & 618 \\
1998 & 178 & 109 & 242 & 72 & 17 & 618 \\
1999 & 167 & 102 & 248 & 71 & 17 & 605 \\
2000 & 165 & 98 & 271 & 70 & 18 & 622 \\
2001 & 158 & 102 & 285 & 71 & 21 & 637 \\
2002 & 151 & 93 & 285 & 77 & 21 & 627 \\
2003 & 145 & 96 & 275 & 83 & 22 & 621 \\
2004 & 129 & 94 & 272 & 88 & 21 & 604 \\
2005 & 119 & 86 & 274 & 89 & 22 & 590 \\
2006 & 93 & 79 & 253 & 86 & 20 & 531 \\
2007 & 76 & 75 & 232 & 86 & 18 & 487 \\
\hline
\end{tabular}

Table 1: Number of pension funds by size - in number of participants - over time.

After our selection, the sample still includes pension funds of very different sizes as shown in Table 1. The number of small funds (150-500 participants) declines over time, whereas the number of large funds (10k-100k and $100 k+$ ) increases. The smaller funds either merged into a bigger fund or transferred their liabilities to an insurance company, and hence disappeared from our dataset. After a merger in year $t$, we discard the receiving fund in years $t$ and $t+1$, to avoid large shocks in the technical reserve figures. Most mergers and terminations concern funds that were too small to be included in the analyses, that is, below 150 participants. ${ }^{4}$

Each year, pension funds must report on the following items, all in current euro or number of participants:

1. Technical reserve $\left(T R_{t}\right)$. This is the actuarial value (using standard life tables) of the liabilities the fund has incurred. Up to 2006, liabilities were discounted by a fixed $4 \%$ interest rate. From 2007, liabilities have been discounted using market based interest rates.

2. Assets $\left(A_{t}\right)$, at market value, split into five categories: fixed income, real estate, stocks, bonds, and other. Dividing total assets by the technical reserve gives the funding ratio, the main indicator of financial health.

\footnotetext{
${ }^{4} \mathrm{~A}$ more detailed description of how we handle mergers and cessations is available from the authors upon request.
} 
3. Benefits $\left(B_{t}\right)$ paid out in the current year, split into straight pension benefits, survivor pension benefits, and disability pension benefits.

4. Premiums $\left(P_{t}\right)$ received in the current year, split into premiums paid by employers and by employees.

5. Participants divided into three categories; active participants, retirees and deferred participants ('sleepers'). The latter are former active participants who no longer contribute premiums, but have not yet reached the age of retirement. They may have quit the labour force, moved to a different pension fund or suffered a decrease in wage income that puts them below the level of eligibility.
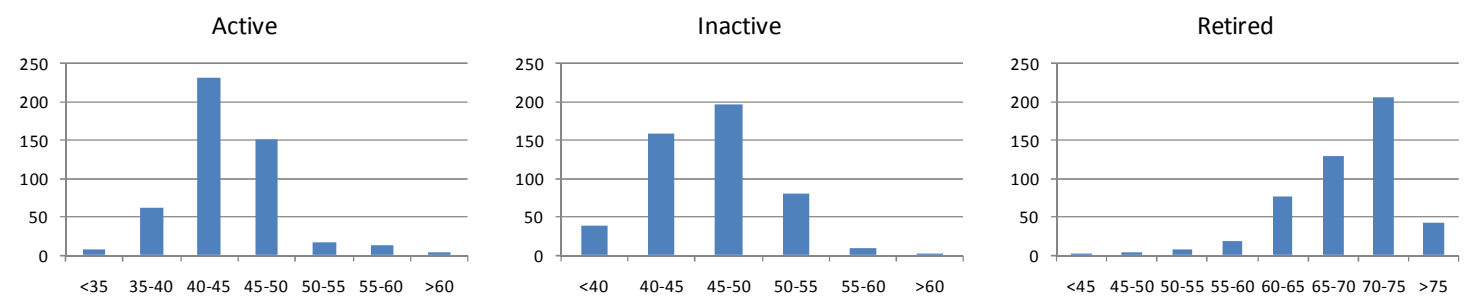

Figure 2: The age distributions for different types of participants in 2007 (in numbers of pension funds)

We know little about the participants of pension funds, except for their classification as active (working), retired or deferred. Only for the last year in our dataset, 2007, we also have the number of active participants, retirees and sleepers split into 5-year cohorts. This data gives us an idea of the demographic structure of each fund. Figure 2 shows the distribution of the average age of pension fund participants for each member type. Table 2 shows the average and median ages across types of funds and types of participants, where the two measures are quite similar. Retirees are, of course, much older than the other participants but, on average, deferred participants are only slightly older than the active participants. If anything, the 80 industry-wide pension funds have, on average, a slightly younger active population than the 399 company pension funds and the eight other funds.

\begin{tabular}{lrrrr}
\hline & All & Industry & Company & Others \\
\hline \# of funds & 487 & 80 & 399 & 8 \\
\hline Active average (median) & $44.3(43.8)$ & $44.2(42.8)$ & $44.3(44.1)$ & $45.3(42.6)$ \\
Sleeper average (median) & $46.3(46.1)$ & $46.8(47.0)$ & $46.1(46.0)$ & $49.1(47.3)$ \\
Retired average (median) & $68.7(70.1)$ & $69.4(70.7)$ & $68.5(69.9)$ & $71.3(71.1)$ \\
\hline
\end{tabular}

Table 2: Average and median ages across types of pension funds and types of participants. 


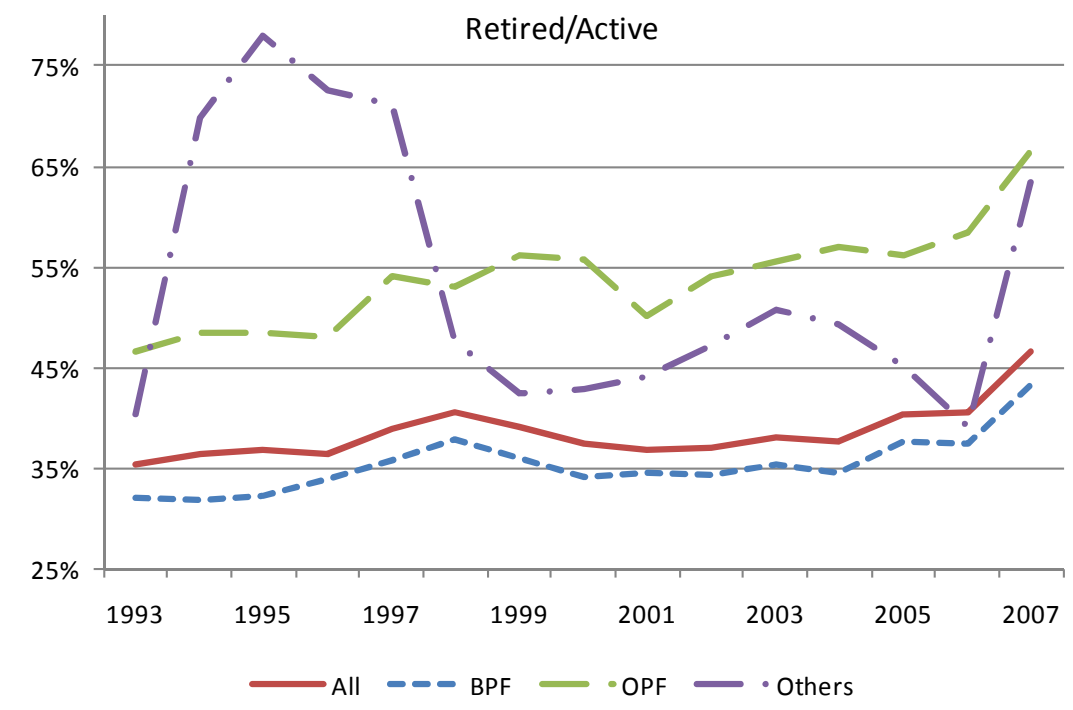

Figure 3: Retired participants per active participants of the fund, for different fund types.

Figure 3 shows the ratio of retired participants over active participants for the sector as a whole and for the three different types of pension funds. The ageing process is clearly visible as the ratio for the Netherlands rises from 35\% in 1993 to $47 \%$ in 2007. Until the mid 1990s early retirement was made very attractive in the Netherlands, lowering the number of active participants and, if the pension fund offered an early retirement scheme, increasing the number of retired. In the late 1990s the government made early retirement less attractive, which resulted in a drop in the retired/active ratio (Euwals, Van Vuuren \& Wolthoff, 2005). The ratio for the 'other' (mostly professional) pension funds follows a volatile path mainly because this group is small and because mergers with and cessations to industry-wide pension funds have a big impact.

\subsection{Recovering behaviour}

The dataset consists mostly of balance sheet items per fund and per year, but does not reveal such pension fund policy parameters as premium rates or degrees of indexation. The latter is an instrument that can be used to influence the level of benefits immediately. In Dutch DB plans, the benefits are specified and guaranteed in nominal rather than real terms. These nominal rights are used to determine a fund's technical reserves. Each year, the pension fund board decides whether to increase benefits and rights in line with the pension plan's stated indexation ambition, that is, adjustment to the general price level or to the contract wages in the sector. This discretionary room for manoeuvre affords the board some limited leeway on the obligation side. Outright nominal devaluation of existing rights is considered only when all other measures fall short. As uniform information on changes in the provided pension policy is lacking, we will use the financial information that is available to develop an indicator of a pension fund's policy stance. 
We aim to unearth facts about pension funds' insurance policies by observing unexpected changes in individual funds' liabilities. Until 2007, pension funds used a fixed $4 \%$ discount rate to discount their future liabilities (a figure that had not changed since 1969). Since 2007, pension funds are required to use the market swap rate. Many large pension funds and part of the other funds used this market rate already in 2006. This caused a clear structural break in the data, as we also will observe later, which is why we drop the observations from 2006. This leaves us with a sample in which the discount rate $r$ is fixed, so the technical reserves are equal to

$$
T R_{t}=\sum_{\tau=t+1}^{\infty} \frac{B_{t, \tau}}{(1+r)^{\tau-t}}
$$

with $B_{t, \tau}$ the benefits the fund expects it has to pay to its retirees in year $\tau$, given the information and accumulated rights in year $t$.

The technical reserves by the end of period $t+1, T R_{t+1}$, can be decomposed into the remaining technical reserves from the previous period after this period's payouts and the present value of the change in expected future payouts.

$$
\begin{aligned}
T R_{t+1} & =(1+r) \sum_{\tau=t+2}^{\infty} \frac{B_{t+1, \tau}}{(1+r)^{\tau-t}} \\
& =(1+r)\left\{\sum_{\tau=t+2}^{\infty} \frac{B_{t+1, \tau}-B_{t, \tau}}{(1+r)^{\tau-t}}+\sum_{\tau=t+1}^{\infty} \frac{B_{t, \tau}}{(1+r)^{\tau-t}}-\frac{B_{t, t+1}}{1+r}\right\} \\
& =(1+r) T R_{t}+(1+r) \sum_{\tau=t+2}^{\infty} \frac{B_{t+1, \tau}-B_{t, \tau}}{(1+r)^{\tau-t}}-B_{t, t+1}
\end{aligned}
$$

The value of the change in expected payouts consists of (i) a term to reflect that old liabilities are now discounted less $(1+r)$, (ii) changes in the expected future benefits $\left(B_{t+1, \tau}-B_{t, \tau}\right)$, and (iii) the removal of benefits paid out this year $\left(B_{t, t+1}\right)$. The change in expected benefits comes from the addition of new rights, but also from newly granted indexation, revaluations due to updated mortality tables, transfers, mergers and acquisitions. Note that the expected payout in period $t+1$ may differ from the actual payout, defined as $B_{t+1}$, for the same reasons.

Observation of the pension related cash flows, that is, the premium income and the actual pension payout, and the current development in the technical reserves, allows us to define $\Gamma$, the unexpected changes in the technical reserve, which acts as an indicator of the pension fund's policy actions:

$$
\Gamma_{t} \equiv T R_{t+1}-\left[(1+r) T R_{t}+P_{t+1}-B_{t+1}\right]
$$

Substitution of Equation (2) into Equation (3) gives: 


$$
\Gamma_{t} \equiv\left\{(1+r) \sum_{\tau=t+2}^{\infty} \frac{B_{t+1, \tau}-B_{t, \tau}}{(1+r)^{\tau-t}}-P_{t+1}\right\}+\left\{B_{t+1}-B_{t, t+1}\right\}
$$

This links the policy action indicator $\Gamma$ to unexpected changes in future payouts during the current period due to policy choices. The first term in parentheses shows the difference between the present value of the change in future benefits and this year's premium payments. Regulation requires that for the fund as a whole, on average, total premium payments to the fund should be equal to the expected present value of the new entitlements, the so-called self-funding premium. ${ }^{5}$ The second term in parentheses shows the difference between expected pension payouts at the beginning of the year and actual payouts.

This $\Gamma$ is an indicator of net transfers between the pension fund and its participants. If pension contributions exceed the present value of the change in expected payouts and/or actual payouts are lower than expected, then there is a net transfer from the participants to the fund, indicated by a negative $\Gamma$. If the $\Gamma$-indicator is positive, what occurs more frequently, there is a net transfer from the fund to its participants. These transfers can take many different forms:

- The fund increases the accumulated nominal pension rights (indexation or backservice ${ }^{6}$ ).

- Contributions do not match the actuarial value of new rights, for instance, due to a recovery premium mark-up designed to increase the funding ratio, or to pension holidays.

- The present value of accumulated pension rights changes, e.g. due to changes in the expected mortality rate. If mortality decreases, and pensioners receive a life annuity, their claim on the fund increases in value.

- Mergers or individual transfers of participants.

- Deviation of the actual mortality of the fund's participants from the average mortality rate occurs.

Note that changes in the value of the liabilities (due to changes in mortality), when taken on board by the pension fund, can be seen as a transfer regardless of whether money changed hands in the current year. Changes in liabilities due to external factors show that the fund is the owner of the respective risk, and serve to insure its participants. Such changes, therefore, imply policy actions. In this sense, only the last two items do not point directly to a transfer between the fund and its participants. The assumption we make in the subsequent analysis is that these shocks are orthogonal to the funds' financial position.

The policy action indicator $\Gamma$ depends on the size of the fund. To make it comparable between funds, we scale it with the level of the technical reserves:

\footnotetext{
${ }^{5}$ The premium may also include a recovery premium mark-up designed to increase the funding ratio.

${ }^{6}$ Backservice is the change of the pension rights due to a change in the actual wage of the participants in a final wage scheme.
} 


$$
\gamma_{t} \equiv \frac{\Gamma_{t}}{T R_{t}}=\frac{T R_{t+1}-P_{t+1}+B_{t+1}}{T R_{t}}-(1+r)
$$

This method of measuring insurance policy action does not allow us to see who the beneficiaries or victims of the pension rights transfers are. More specifically, we cannot distinguish whether a transfer affects the active or the retired participants of the fund.

\section{Estimating pension policy reactions}

To determine the impact of a fund's solvency on its pension policy, we estimate the relationship between the fund's net transfer to its participants $(\gamma)$ and the funding ratio $F R_{i, t}=A_{i, t} / T R_{i, t}$. Transfers between the fund and its participants are conditional on the financial state of the fund; in fact, levying extra premiums or moderating rights indexation in times of reduced solvency, and vice versa, are widely used policy measures. If we can recover this relationship, this would confirm that $\gamma_{t}$ is a useful indicator of transfers. The characteristics of this relationship may tell us more about the reaction of funds' pension policies to their funding ratios. Is the marginal effect of a change in the funding ratio constant as in a linear relationship, or non-linear, e.g. do regime breaks exist?

\subsection{The impact of the funding ratio}

In its simplest form, the relation we estimate is

$$
\gamma_{i, t}=\alpha_{i}+\beta F R_{i, t}+\epsilon_{i, t}
$$

We use the panel dataset at our disposal to estimate a pension fund specific fixed effect $\alpha_{i}$ that accounts for the fact that different pension funds may take different approaches to plan sponsorship, leading to different average rates of pension transfers.

Figure 4 shows the relation between the median $\gamma$ and the median one-year lagged funding ratio over time. As this figure shows, there is a positive relation between these two variables from the first observation in 1994 until 2005. The years 2006 and 2007 show a clear break, which can be explained by changes in solvency regulation in 2007: pension funds must use the market swap rate to discount their future liabilities, instead of the fixed $4 \%$ discount rate. ${ }^{7}$ The discount rates in 2006 and 2007 were well above $4 \%$ for all maturities, resulting in lower technical reserves, which

\footnotetext{
${ }^{7}$ To measure the effect of a market based term structure on a fund's technical reserves, taking the maturity of the liabilities into account, one needs to know the demographic composition of the pension fund's participants and their individual pension rights. As this information is not available in our dataset, we cannot reproduce the technical reserve using the fixed interest rate from the figure computed with the market rate.
} 
explains the low $\gamma^{\prime} s$ in these years. Because of this change in the calculation of the technical reserves, we exclude the years 2006 and 2007 from our estimations.

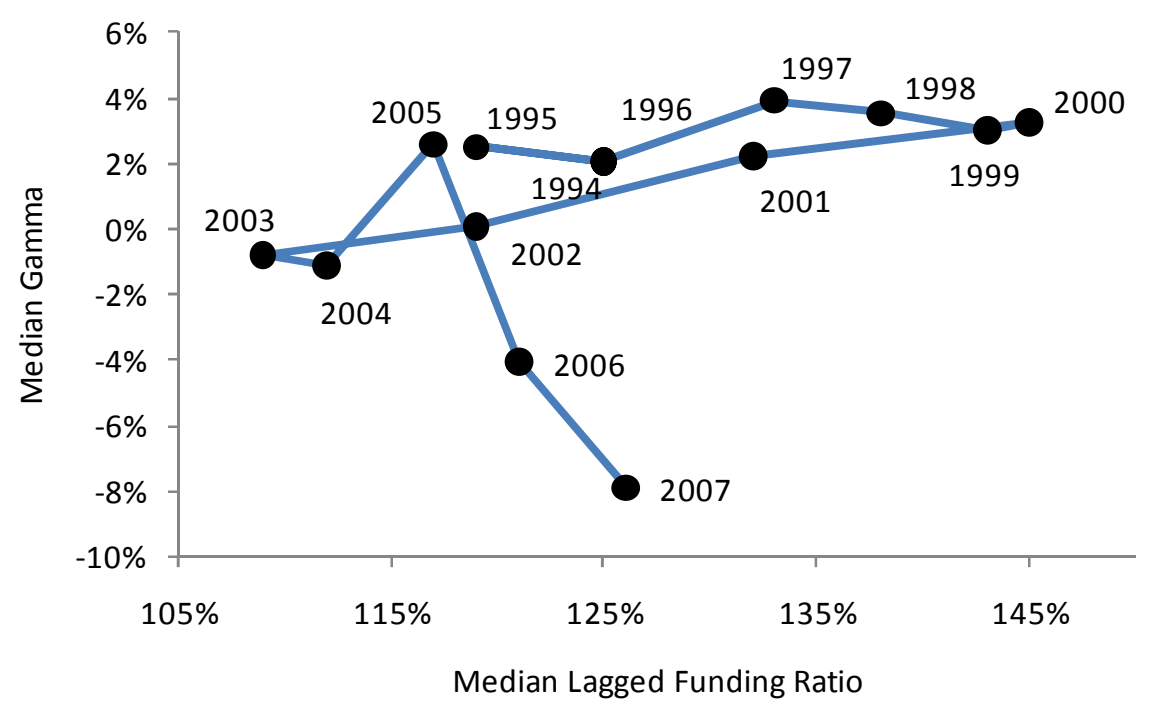

Figure 4: The median lagged funding ratio versus the median $\gamma$

In preliminary estimations we experimented with the lag structure of Equation (6). Using the current funding ratio to explain $\gamma$ is not realistic as pension funds take pension policy actions only after new information on their solvency is released, that is not until the next year. ${ }^{8}$ Using the lagged value of the funding ratio $(F R)$ takes care of this, but there is no reason to include it as the only explanatory variable. In principle, the value of $F R$ two (or more) years lagged can be included and may provide extra information on the impact of the funding ratio. In all specifications used, however, we find that adding extra lags of $F R$ does not contribute to the explanatory power of the model.

Apart from the funding ratio we have indicators of the demographic composition of the pension fund, its size and its type. However, those variables show little or no variation beyond a simple time trend. This means that we can only estimate fixed-effect panel regressions with the funding ratio as single explanatory variable. We start with this strategy, and later continue to explore models with more explanatory variables but without fixed effects.

Regulation in the Netherlands as in force since 2007 assigns special meaning to funding ratios of $105 \%$ (minimum requirement) and around $127 \%$ (long term requirement for a standard pension

\footnotetext{
${ }^{8}$ The current funding ratio is also problematic from an econometric point of view as this variable would result in a spurious regression. Indeed, unexpected changes in the level of fund obligations - through e.g. demographic realizations or decisions about indexation - would show up in both the funding ratio and the transfer rate.
} 
fund with $50 \%$ equities and $50 \%$ bonds; this buffer is necessary for e.g. full indexation). ${ }^{9}$ These thresholds reflect existing common sense: a pension fund needs a funding ratio well above $100 \%$ to remain solvent, while a larger buffer is needed for in the long run. They are also the result of a long negotiation process between the supervisor, the government and representatives of employers and employees. Preliminary information on the new regime circulated since 2002. Long before 2007, pension funds may have changed their behaviour if their funding ratio fell below these special values, even before they were given their formal status in the new regulatory regime. The threshold methodology of Hansen $(1999,2000)$ allows for such changes in pension funds' policy regimes. For a one-threshold specification with varying intercept and coefficient, the estimated equation changes to:

$$
\gamma_{i, t}= \begin{cases}\alpha_{i}^{0}+\beta^{0} F R_{i, t-1}+\epsilon_{i, t}, & F R_{i, t-1} \leq T \\ \alpha_{i}^{1}+\beta^{1} F R_{i, t-1}+\epsilon_{i, t}, & F R_{i, t-1}>T\end{cases}
$$

where the level of the threshold $T$ is estimated simultaneously with the other parameters.

We estimate various panel fixed effects versions of the threshold model with one and two breaks; a third break was not statistically significant. Figure 5 and Figure 6 show the estimated relationships for respectively the one- and two-break models.

Figure 5 shows the estimates of five variants of Equations (6) and (7): (i) Equation (6) without a jump, (ii) a step function with just the average level before and after a single break, (iii) Equation (7) with varying intercepts with the same coefficient of the funding ratio before and after the break, (iv) Equation (7) with regime specific gradients but equal intercepts, and (v) Equation (7) with regime specific intercept and gradient. Figure 6 shows the same specifications, but with two possible breakpoints. The appendix presents the exact specification of all the estimated equations. Note that these are all fixed effects results which give each fund its own intercept. Table 3 and Table 4 report the estimated coefficients for respectively the one- and two-break models in more detail.

The first result is that the growth of additional pension rights increases significantly with the funding ratio. ${ }^{10}$ This confirms our obvious expectations and validates our indirect approach. The

\footnotetext{
${ }^{9}$ The required funding ratio of around $127 \%$ for a standard pension fund is determined, so that the probability of underfunding within one year is limited to $2.5 \%$.

${ }^{10}$ Note that the coefficient of the funding ratio (FR) in Table 3 after T indicates how the coefficient of FR changes after the break. So, for the 'no common coefficients' variant the coefficient is 0.480 before the break and $0.480-0.379=0.101$ after the break.
} 


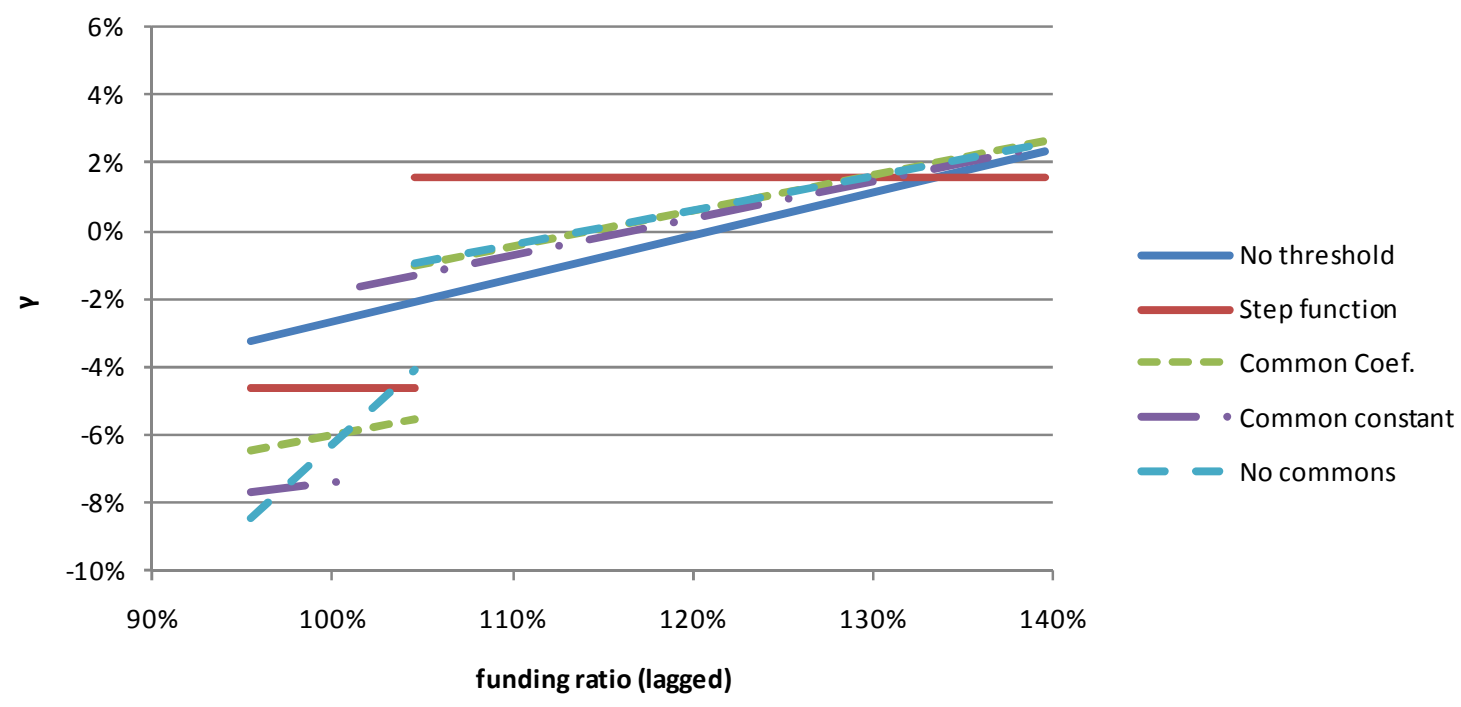

Figure 5: Estimated relationship between $\gamma$ and the lagged funding ratio with one break.

second outcome is that this positive effect of the funding ratio on the pension fund's generosity is not linear but exhibits statistically significant breaks or jumps. This result is robust across to various specifications used. A point estimate for the first break is either at $102 \%$ or $104 \%$ in both the one-break and the two-break specifications. The jump at the first break is between 3 and 6

\begin{tabular}{lrrrrr}
\hline & No threshold & Step function & $\begin{array}{r}\text { Common FR } \\
\text { coefficient }\end{array}$ & $\begin{array}{r}\text { Common } \\
\text { constant }\end{array}$ & $\begin{array}{r}\text { No common } \\
\text { coefficients }\end{array}$ \\
\hline Constant & $-0.153[-8.5]$ & $-0.046[-6.4]$ & $-0.163[-9.1]$ & $-0.127[-6.9]$ & $-0.543[-2.7]$ \\
Funding ratio & $0.126[9.0]$ & & $0.103[7.1]$ & $0.053[2.7]$ & $0.480[2.4]$ \\
\hline Threshold $(\mathrm{T})$ & & $105 \%$ & $105 \%$ & $102 \%$ & $105 \%$ \\
F value & 59.3 & 29.6 & 28.8 & 33.2 \\
$\mathrm{P}$ (no break at $\mathrm{T}$ ) & & $<0.01$ & $<0.01$ & $<0.01$ & $<0.01$ \\
\hline Constant $(\geq \mathrm{T}$ ) & & $0.062[7.7]$ & $0.045[5.4]$ & & $0.428[2.1]$ \\
Funding ratio $(\geq \mathrm{T})$ & & & & $0.056[5.4]$ & $-0.379[-1.9]$ \\
Jump at T & & $6.2 \% \mathrm{pt}$ & $4.5 \% \mathrm{pt}$ & $5.7 \% \mathrm{pt}$ & $3.2 \% \mathrm{pt}$ \\
\hline Number of obs. & 1637 & 1637 & 1637 & 1637 & 1637 \\
obs $<\mathrm{T}$ & & 210 & 210 & 114 & 210 \\
obs $\geq \mathrm{T}$ & & 1427 & 1427 & 1523 & 1427 \\
$\mathrm{R}^{2}$ & & 0.042 & 0.076 & 0.075 & 0.078 \\
\hline
\end{tabular}

Table 3: Estimated relationship between $\gamma$ and the lagged funding ratio with one break. (t-values within brackets) 
percentage points in all specifications, with an average of 4.8 percentage points in the one-break specifications and 4.9 percentage points in the two-break specifications. The second jump is estimated at a funding ratio between $125 \%$ and $132 \%$, depending on the specification. The jump is smaller than the first one, but still ranges from 1 to 4 percentage points with an average of 2.5 percentage points.

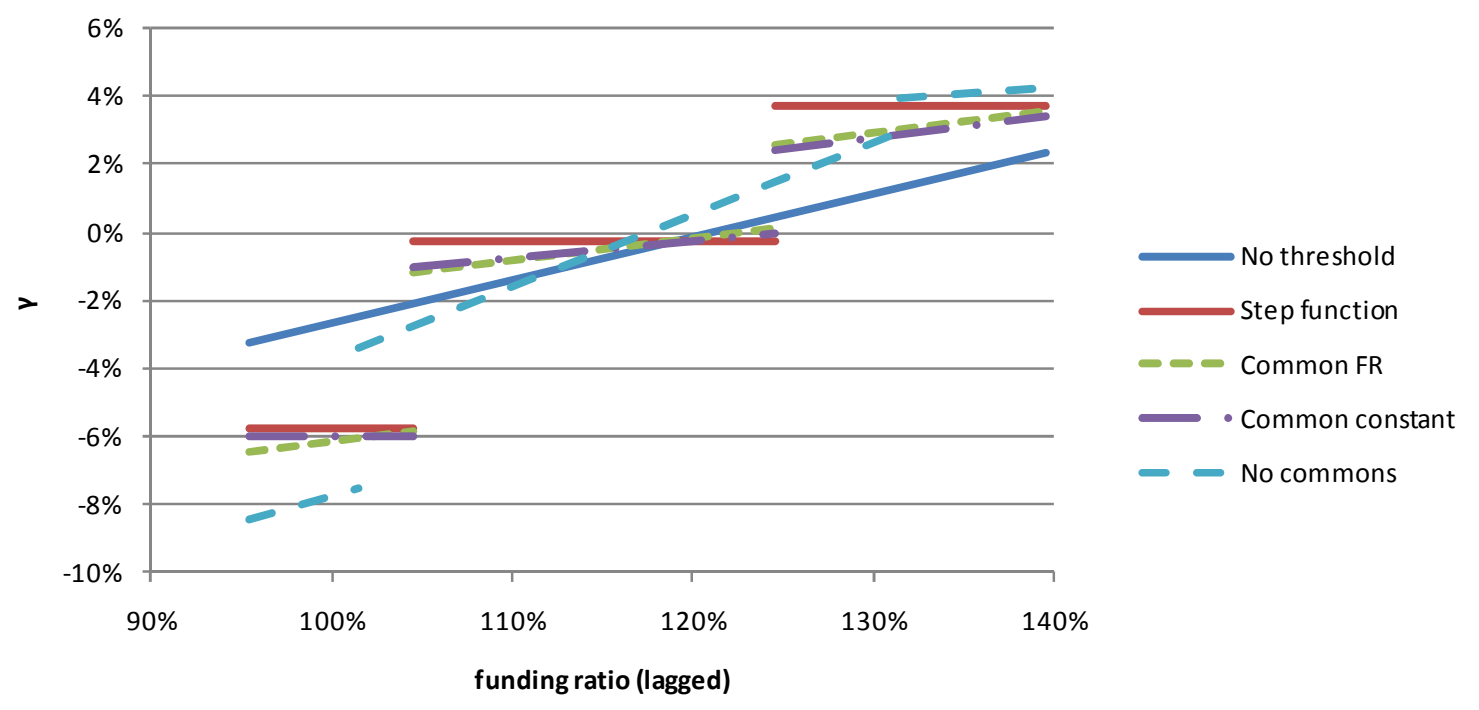

Figure 6: Estimated relationship between $\gamma$ and the lagged funding ratio with two breaks.

These estimation results show that the relationship between a pension fund's transfer to its participants and its funding ratio is nonlinear. When the funding ratio falls below $105 \%$, the transfer rate $\gamma$ drops about 4 percentage points. Less robust, but still significant, is the nonlinearity around a funding ratio of $130 \%$, where the transfer rate makes another jump of around half that size. Between the two jumps, there exists a weak, positive, relation between the pension transfer indicator $\gamma$ and the funding ratio.

The form of the relationship between the funding ratio and the transfer indicator $\gamma$ shows the existence of distinct pension policy regimes on either side of the thresholds. Below the $105 \%$ threshold, funds transfer significantly less to their participants. In this situation, a net transfer from participants to the fund is more likely. This changes dramatically when funds cross the threshold and the situation is seen as quite safe. At that point, there is only a weak impact of funding on transfers. A second behavioural change occurs at high funding levels, where transfers to participants are increased but with a lesser (though statistically significant) jump.

The location of the first break can be explained by a desire to stay solvent. Although participation in the pension plan is (and was) mandatory and participants could not claim entitlements 
immediately, pension funds aim to possess sufficient assets to cover their liabilities. The second break coincides with the solvency requirement where under new regulation pension funds are also allowed to provide full indexation to prices or wages.

\begin{tabular}{|c|c|c|c|c|c|}
\hline & \multicolumn{5}{|c|}{ Type of model } \\
\hline & No threshold & Step function & $\begin{array}{r}\text { Common } F R \\
\text { coefficient }\end{array}$ & $\begin{array}{l}\text { Common } \\
\text { constant }\end{array}$ & $\begin{array}{l}\text { No common } \\
\text { coefficients }\end{array}$ \\
\hline Constant & $-0.153[-8.5]$ & $-0.057[-7.8]$ & $-0.125[-6.0]$ & $-0.062[-2.4]$ & $-0.239[-0.9]$ \\
\hline Funding ratio & $0.126[9.0]$ & & $0.063[3.4]$ & $0.002[0.1]$ & $0.162[0.6]$ \\
\hline Threshold $\left(\mathrm{T}_{1}\right)$ & & $105 \%$ & $105 \%$ & $105 \%$ & $102 \%$ \\
\hline F value & & 46.0 & 32.0 & 33.2 & 12.3 \\
\hline $\mathrm{P}\left(\right.$ no break at $\left.\mathrm{T}_{1}\right)$ & & $<0.01$ & $<0.01$ & $<0.01$ & $<0.05$ \\
\hline Constant $\left(\geq \mathrm{T}_{1}\right)$ & & $0.055[6.8]$ & $0.047[5.7]$ & & $-0.010[-0.0]$ \\
\hline Funding ratio $\left(\geq \mathrm{T}_{1}\right)$ & & & & $0.048[5.8]$ & $0.050[0.2]$ \\
\hline Jump at $\mathrm{T}_{1}$ & & $5.5 \% \mathrm{pt}$ & $4.7 \% \mathrm{pt}$ & $5.0 \% \mathrm{pt}$ & $4.1 \% \mathrm{pt}$ \\
\hline Threshold $\left(T_{2}\right)$ & & $125 \%$ & $125 \%$ & $125 \%$ & $132 \%$ \\
\hline F value & & 51.0 & 12.2 & 10.4 & 22.6 \\
\hline$P\left(\right.$ no break at $\left.T_{2}\right)$ & & $<0.01$ & $<0.01$ & $<0.01$ & $<0.01$ \\
\hline Constant $\left(\geq T_{2}\right)$ & & $0.040[7.1]$ & $0.025[3.5]$ & & $0.247[4.3]$ \\
\hline Funding Ratio $\left(\geq T_{2}\right)$ & & & & $0.019[3.2]$ & $-0.180[-4.0]$ \\
\hline Jump at $T_{2}$ & & $4.0 \% \mathrm{pt}$ & $2.5 \% \mathrm{pt}$ & $2.4 \% \mathrm{pt}$ & $1.0 \% \mathrm{pt}$ \\
\hline Number of obs. & 1637 & 1637 & 1637 & 1637 & 1637 \\
\hline obs $<\mathrm{T}_{1}$ & & 210 & 210 & 210 & 114 \\
\hline $\mathrm{T}_{1} \leq$ obs $<\mathrm{T}_{2}$ & & 703 & 703 & 703 & 969 \\
\hline$o b s \geq T_{2}$ & & 724 & 724 & 724 & 554 \\
\hline$R^{2}$ & 0.056 & 0.076 & 0.084 & 0.082 & 0.091 \\
\hline
\end{tabular}

Table 4: Estimated relationship between $\gamma$ and the lagged funding ratio with two breaks. (t-values within brackets)

The transition from final wage to average wage schemes during 2002-2004 when, after the end of the dot-com bubble, the funding ratio fell below the lower threshold, has influenced the response instruments of the pension funds. Under a final wage scheme pension entitlements increase with the wages of the active participants, the so-called backservice. Under an average wage scheme, such backservice is absent, so that in the presence of wage growth no automatic increase occurs of the technical reserves. This limits the increase in pension entitlements, hence contributes to a possible lower gamma. 


\subsection{Role of demographics, type, and size of the pension fund}

In the previous section we regressed $\gamma$ on the lagged funding ratio with fund specific fixed effects. These fixed effects indicate that some pension funds are systematically more generous in their transfers to the participants than others. This section explains these differences between funds from observables such as the average age of the fund's participants, the shares of the various classes of participants, and the type or size of pension fund. These characteristics are either roughly constant over time - the type of a fund does not change, and member shares only change very gradually - or we only have observations for the last year in our sample. This means that we cannot run fixed-effect panel regressions, as the coefficient on the observables would not be identified. Instead we resort to pooled regressions, where we do not estimate a fixed 'average transfer rate' for each individual pension fund. The additional variables will pick up (part of the) systematic differences between pension funds.

\subsubsection{Demographics}

For 2007 we have the number of participants per category - active, deferred, and retired - in fiveyear age cohorts. From these cohort sizes we can proxy the average age of each group; Figure 2 already provided an overview of these age distributions. Table 5 provides the relationship between the average ages and $\gamma$ for various specifications of the link between $\gamma$ and the lagged funding ratio. Note that by using the 2007 age distribution in regressions about earlier years, we assume that the demographic characteristics tend to be constant. That is, we use the fact that demographic measures generally move slowly over time and assume that the participants' age distribution in 2007 contains information on the (relative) average ages of participant types in earlier years. The empirical results demonstrate that this assumption makes sense.

Table 5 shows that if the average age of the retired increases 10 years, the pension fund's transfer indicator $\gamma$ over the entire sample is, on average, 2.1 percentage points higher per year. In such a grey pension fund, the (older) participants have interest in generous transfers, as the risks are shifted to the (further) future. The age effect of active participants is also negative: an increase in the age of active participants implies a decrease of $\gamma$ of 3.0 percentage points. The young participants of such a green pension fund can bear risks better: negative shocks can be compensated by working more hours a week, or by postponing retirement, so this pension fund may be more generous. These joint effects show a U-shaped pattern when generous behaviour is plotted against the average age of a pension fund's participants. Finally, the inclusion of the average age instead of a fund-specific fixed effect has no significant effect on the relation between the lagged funding ratio and $\gamma$ : the size of the coefficients, the location of the breaks and the size of the jump are all similar to the fixed effect regressions in Section 4.1.

Another indicator of the demographics of a pension fund is given by the relative shares of active participants, inactive participants and retirees. Table 6 shows again that older funds - with a 
larger share of retirees - have a higher average $\gamma$. The shares of the active, sleepers and retirees add up to 1 , forcing us to drop one variable; we select the share of the sleepers. The share of the active participants does not have a significant effect on $\gamma$ in any specification, but the share of the retirees does: its coefficient is significant at the $1 \%$ level in all specifications. A 10 percentage points bigger share of the retired increases $\gamma$ by an average of 1.3 percentage points.

\begin{tabular}{lrrr}
\hline & \multicolumn{3}{c}{ Type of model } \\
\hline & No threshold & Common coefficients & No commons \\
\hline Constant & $-0.207[-6.2]$ & $-0.222[-6.7]$ & $-0.227[-1.0]$ \\
Funding ratio & $0.063[6.3]$ & $0.007[0.4]$ & $0.063[0.3]$ \\
Age active & $-0.0030[-4.8]$ & $-0.0029[-4.7]$ & $-0.0030[-4.8]$ \\
Age deferred & $0.0028[3.6]$ & $0.0025[3.4]$ & $0.0024[3.2]$ \\
Age retirees & $0.0021[3.9]$ & $0.0021[3.8]$ & $0.0021[3.9]$ \\
\hline Threshold $\left(\mathrm{T}_{1}\right)$ & & $102 \%$ & $102 \%$ \\
Constant $\left(\geq \mathrm{T}_{1}\right)$ & & $0.043[4.5]$ & $-0.011[-0.1]$ \\
Funding ratio $\left(\geq \mathrm{T}_{1}\right)$ & & & $0.041[0.2]$ \\
\hline Threshold $\left(\mathrm{T}_{2}\right)$ & & $125 \%$ & $125 \%$ \\
Constant $\left(\geq \mathrm{T}_{2}\right)$ & & $0.026[3.5]$ & $0.151[2.4]$ \\
Funding Ratio $\left(\geq \mathrm{T}_{2}\right)$ & & & $-0.107[-2.0]$ \\
\hline Number of observations & 1168 & 1168 & 1168 \\
obs $<\mathrm{T}_{1}$ & & 81 & 81 \\
$\mathrm{~T}_{1} \leq$ obs $<\mathrm{T}_{2}$ & & 571 & 571 \\
obs $\geq \mathrm{T}_{2}$ & & 516 & 516 \\
$\mathrm{R}^{2}$ & & 0.119 & 0.122 \\
\hline
\end{tabular}

Table 5: Effect of the participants' ages on transfers $(\gamma)$

Both indicators of the 'age' of a pension fund's participants point in the same direction: grey funds have higher transfer rates to participants. From our data we cannot infer which group stands to benefit from this transfer. It could be due to lower pension premiums or higher indexation. Note that it is not the level of the payout that creates this higher $\gamma$ (grey funds always have large outflows simply because they are in the payout phase), but the ratio of benefits over technical reserves. Note also that retirees do not generally have a formal vote in pension fund boards. A possible explanation is that the employee representatives (e.g. labour unions) take the interests of retirees into account in order to obtain higher indexation. 


\begin{tabular}{lrrr}
\hline & \multicolumn{3}{c}{ Type of model } \\
\hline No threshold & Common coefficient & No commons \\
\hline Fundint ratio & $-0.073[-4.2]$ & $-0.066[-3.1]$ & $0.103[0.6]$ \\
Share active & $0.041[4.0]$ & $-0.012[-0.8]$ & $-0.184[-1.1]$ \\
Share retirees & $0.004[0.3]$ & $0.010[0.6]$ & $0.011[0.7]$ \\
\hline Threshold $\left(\mathrm{T}_{1}\right)$ & $0.123[5.6]$ & $0.125[5.8]$ & $0.123[5.7]$ \\
Constant $\left(\geq \mathrm{T}_{1}\right)$ & & $102 \%$ & $102 \%$ \\
Funding ratio $\left(\geq \mathrm{T}_{1}\right)$ & & $0.053[5.2]$ & $-0.222[-1.3]$ \\
\hline Threshold $\left(\mathrm{T}_{2}\right)$ & & & $0.266[1.5]$ \\
Constant $\left(\geq \mathrm{T}_{2}\right)$ & & $125 \%$ & $132 \%$ \\
Funding ratio $\left(\geq \mathrm{T}_{2}\right)$ & & $0.022[2.8]$ & $0.163[2.9]$ \\
\hline Number of observations & 1637 & & $-0.116[-2.6]$ \\
obs $<\mathrm{T}_{1}$ & & 1637 & 1637 \\
$\mathrm{~T}_{1} \leq$ obs $<\mathrm{T}_{2}$ & & 114 & 114 \\
obs $\geq \mathrm{T}_{2}$ & & 799 & 969 \\
$\mathrm{R}^{2}$ & & 724 & 554 \\
\hline
\end{tabular}

Table 6: Effect of group share on transfers $(\gamma)$

\subsection{Size and type of pension funds}

Table 7 shows the regression results if we include the logarithm of the total number of participants as a measure of size alongside the lagged funding ratio. The results show that larger funds have a higher $\gamma$; the coefficient for our sample averages $0.5 \%$. This implies that the rate of transfer from a pension fund with one million participants is 1.2 percentage points higher than that of a fund with 10,000 participants. The effect of the size is significant at the $1 \%$ level in all specifications. Inclusion of the pension fund size has no significant effect on the coefficients or breaks of the lagged funding ratio. The first break always occurs between $101 \%$ and $104 \%$, the second break lies between $124 \%$ and $132 \%$.

A possible explanation for this higher $\gamma$ are the economies of scale these bigger funds have (see Bikker \& De Dreu, 2009). Lower costs imply that a larger part of the paid premiums can be used to create new pension rights, either permitting lower premiums or increasing the next year's technical reserves. 


\begin{tabular}{lrrr}
\hline & \multicolumn{3}{c}{ Type of model } \\
\hline No threshold & Common coefficient & No commons \\
\hline Constant & $-0.096[-5.2]$ & $-0.084[-3.7]$ & $0.083[0.5]$ \\
Funding ratio & $0.053[5.1]$ & $-0.008[-0.5]$ & $-0.177[-1.0]$ \\
Log size & $0.0048[3.0]$ & $0.0053[3.3]$ & $0.0051[3.2]$ \\
\hline Threshold $\left(\mathrm{T}_{1}\right)$ & & $102 \%$ & $102 \%$ \\
Constant $\left(\geq \mathrm{T}_{1}\right)$ & & $0.055[5.3]$ & $-0.250[-1.4]$ \\
Funding ratio $\left(\geq \mathrm{T}_{1}\right)$ & & & $0.292[1.6]$ \\
\hline Threshold $\left(\mathrm{T}_{2}\right)$ & & $125 \%$ & $132 \%$ \\
Constant $\left(\geq \mathrm{T}_{2}\right)$ & $0.026[3.3]$ & $0.206[3.7]$ \\
Funding ratio $\left(\geq \mathrm{T}_{2}\right)$ & & & $-0.148[-3.3]$ \\
\hline Number of observations & 1637 & 1637 & 1637 \\
obs $<\mathrm{T}_{1}$ & & 114 & 114 \\
$\mathrm{~T}_{1} \leq$ obs $<\mathrm{T}_{2}$ & & 799 & 969 \\
obs $\geq \mathrm{T}_{2}$ & & 724 & 554 \\
$\mathrm{R}^{2}$ & & 0.043 & 0.047 \\
\hline
\end{tabular}

Table 7: Effect of pension funds' sizes on transfers $(\gamma)$

Finally, Table 8 shows the results if we include type of fund dummies. We classify each fund into one of three types: industry-wide pension funds, company pension funds and 'others'. This third category consists of professional group funds (including non-academic occupational groups) and three special funds created for legal reasons. Since every fund has a type and funds typically do not change type, we cannot include dummy variables for all three types in the regression model. We only observe the difference between the first two types and the 'others' as baseline.

Table 8 shows that industry-wide pension funds, on average, have a 6.2 percentage points to 6.8 percentage points lower $\gamma$ than company pension funds. The other coefficients do not change significantly and the jumps at the thresholds remain of the same magnitude. One potential explanation for the relative generosity of company pension funds is that they have the support of a sponsor which may help to absorb negative shocks.

\section{Conclusions}

This paper investigates how pension rights are adjusted in response to developments in the pension funds' funding rate. Changes in pension rights are not recorded systematically, but we use a sample of more than 1,000 Dutch pension funds from 1993 to 2007 to proxy changes in pension rights per pension fund and per year. We exclude funds with fewer than 150 participants, as they 


\begin{tabular}{lrrr}
\hline & \multicolumn{3}{c}{ Type of fund } \\
\hline & No threshold & Common coefficient & No commons \\
\hline Constant & $-0.044[-2.6]$ & $-0.031[-1.4]$ & $0.109[0.4]$ \\
Funding ratio & $0.053[5.1]$ & $-0.001[-0.1]$ & $-0.141[-0.5]$ \\
Industry-wide fund & $-0.081[-5.5]$ & $-0.075[-5.1]$ & $-0.076[-5.3]$ \\
Company fund & $-0.012[-1.1]$ & $-0.012[-1.1]$ & $-0.014[-1.2]$ \\
\hline Threshold $\left(\mathrm{T}_{1}\right)$ & & $102 \%$ & $102 \%$ \\
Constant $\left(\geq \mathrm{T}_{1}\right)$ & & $0.049[4.7]$ & $-0.253[-0.9]$ \\
Funding ratio $\left(\geq \mathrm{T}_{1}\right)$ & & & $0.285[1.0]$ \\
\hline Threshold $\left(\mathrm{T}_{2}\right)$ & & $125 \%$ & $137 \%$ \\
Constant $\left(\geq \mathrm{T}_{2}\right)$ & & $0.023[3.0]$ & $0.207[3.9]$ \\
Funding ratio $\left(\geq \mathrm{T}_{2}\right)$ & & & $-0.159[-4.0]$ \\
\hline Number of observations & 1610 & 1610 & 1610 \\
obs $<\mathrm{T}_{1}$ & & 111 & 111 \\
$\mathrm{~T}_{1} \leq$ obs $<\mathrm{T}_{2}$ & & 783 & 1038 \\
obs $\geq \mathrm{T}_{2}$ & & 716 & 461 \\
$\mathrm{R}^{2}$ & & 0.063 & 0.067 \\
\hline
\end{tabular}

Table 8: Effect of types of pension funds on transfers $(\gamma)$

generally have different objectives, and we drop observations from the years 2006-2007 because a new pension regime introduced in 2007 , and already widely applied in 2006 , causes a break. Using a panel data approach, the first finding is that pension rights increase with the funding rate, in line with expectations. On average, an increase of the funding ratio by 10 percentage points adds 1.0 percentage point to the participants' pension rights. The second finding is that this relationship between newly assigned pension rights and the funding ratio includes two highly significant breaks. When the funding ratio falls below $105 \%$, the transfer of pension rights drops by 4 percentage points. When the funding ratio reaches $130 \%$, the transfer rate increases by 2 percentage points. These breakpoints in the 1993-2005 sample exhibit a remarkable coincidence with essential funding levels in the new regulatory regime, which has been developed during but was established after the sample period: the funding ratio of $105 \%$ is a minimum requirement, whereas a ratio of around $125-130$ is the required level for a standard pension fund, needed for e.g. full indexation.

If we expand our model with additional explanatory variables such as the age distribution of participants, the type of participants and the type of pension fund, we lose the panel structure with pension-fund specific fixed effects, as these additional explanatory variables have limited or no variation over time. Using pooled regression, we find that indicators of the average age of a pension fund's participants have a positive impact on the funds' generosity. With respect to types of participants, the share of retirees is an especially important determinant. A possible explanation is that participants of higher age cohorts have more influence, because they are overrepresented 
in labour unions. Apparently, the instrument of adjusting indexation, which has a greater effect on the technical reserve, the higher the share of retirees is, dominates the instrument of pension premium adjustment, which regards the active participants only. We also find that larger funds are more generous, possibly reflecting better scale efficiency. Finally, company pension funds are more generous than industry-wide funds, likely because the first type has the benefit of a de-facto risk absorbing sponsor company. Al these extensions of our model confirm our earlier results of increasing pension rights when funding rates are higher and the existence of two highly significant breaks at plausible funding rate levels and with substantial jumps.

\section{References}

ABP (2010), Annual Report 2010, Algemeen Burgerlijk Pensioenfonds, Heerlen/Amsterdam.

Bikker, J.A., \& De Dreu, J. (2009), 'Operating costs of pension funds: the impact of scale, governance, and plan design', Journal of Pension Economics and Finance, vol. 8, pp. 63-89.

Bikker, J.A., Broeders, D.W.G.A., \& De Dreu, J. (2010), 'Stock market performance and pension fund investment policy: rebalancing, free float, or market timing', International Journal of Central Banking, June, pp. 53-79.

Bikker, J.A., Broeders, D.W.G.A., Hollanders, D. A., \& Ponds, E.H. (2011), 'Pension Funds' Asset Allocation and Participant Age: A Test of the Life-Cycle Model', Journal of Risk and Insurance, (forthcoming).

Bikker, J.A., Steenbeek, O.W., \& Torracchi, F. (2011), 'The impact of scale, complexity, and service quality on the administrative costs of pension funds: A cross-country comparison', Journal of Risk and Insurance, (forthcoming).

Bovenberg, A.L., Koijen, R., Nijman, T., \& Teulings, C.N. (2007), 'Saving and investing over the life cycle and the role of collective pension funds', De Economist, pp. 347-415.

De Dreu, J., \& Bikker, J.A. (2009), 'Pension Fund Sophistication and Investment Policy', DNB Working Paper no. 211.

De Nederlandsche Bank (2011), 'Macroeconomic Statistics Pension Funds Table 8.1 and Register Pension Funds Table 8.17', Downloadable from http://www.statistics.dnb.nl/

Euwals, R., Van Vuuren, D., \& Wolthoff, R., 2005, 'Early Retirement Behaviour in the Netherlands: Evidence from a Policy Reform', CPB Discussion Paper, CPB Netherlands Bureau for Economic Policy Analysis, The Hague.

Hansen, B.E. (1999), 'Threshold effects in non-dynamic panels: Estimation, testing and inference', Econometrica, vol. 93, pp. 345-368.

Hansen, B.E. (2000), 'Sample Splitting and Threshold Estimation', Econometrica, 68, pp. 575-603. 


\section{Appendix: Estimated equations}

We estimate the following one break specifications:

$$
\begin{aligned}
& \gamma_{i, t}= \begin{cases}\alpha_{i}^{0}+\epsilon_{i, t}, & F R_{i, t-1} \leq T \\
\alpha_{i}^{1}+\epsilon_{i, t}, & F R_{i, t-1}>T\end{cases} \\
& \gamma_{i, t}= \begin{cases}\alpha_{i}+\beta^{0} F R_{i, t-1}+\epsilon_{i, t}, & F R_{i, t-1} \leq T \\
\alpha_{i}+\beta^{1} F R_{i, t-1}+\epsilon_{i, t}, & F R_{i, t-1}>T\end{cases} \\
& \gamma_{i, t}= \begin{cases}\alpha_{i}^{0}+\beta F R_{i, t-1}+\epsilon_{i, t}, & F R_{i, t-1} \leq T \\
\alpha_{i}^{1}+\beta F R_{i, t-1}+\epsilon_{i, t}, & F R_{i, t-1}>T\end{cases} \\
& \gamma_{i, t}= \begin{cases}\alpha_{i}^{0}+\beta^{0} F R_{i, t-1}+\epsilon_{i, t}, & F R_{i, t-1} \leq T \\
\alpha_{i}^{1}+\beta^{1} F R_{i, t-1}+\epsilon_{i, t}, & F R_{i, t-1}>T\end{cases}
\end{aligned}
$$

(Common funding rate coefficient)

(Common constant)

(No common coefficients)

For the two break specifications, we estimate:

$$
\begin{aligned}
& \gamma_{i, t}= \begin{cases}\alpha_{i}^{0}+\epsilon_{i, t}, & F R_{i, t-1} \leq T_{1} \\
\alpha_{i}^{1}+\epsilon_{i, t}, & T_{1}<F R_{i, t-1} \leq T_{2} \\
\alpha_{i}^{2}+\epsilon_{i, t}, & F R_{i, t-1}>T_{2}\end{cases} \\
& \gamma_{i, t}= \begin{cases}\alpha_{i}+\beta^{0} F R_{i, t-1}+\epsilon_{i, t}, & F R_{i, t-1} \leq T_{1} \\
\alpha_{i}+\beta^{1} F R_{i, t-1}+\epsilon_{i, t}, & T_{1}<F R_{i, t-1} \leq T_{2} \\
\alpha_{i}+\beta^{2} F R_{i, t-1}+\epsilon_{i, t}, & F R_{i, t-1}>T_{2}\end{cases} \\
& \gamma_{i, t}= \begin{cases}\alpha_{i}^{0}+\beta F R_{i, t-1}+\epsilon_{i, t}, & F R_{i, t-1} \leq T_{1} \\
\alpha_{i}^{1}+\beta F R_{i, t-1}+\epsilon_{i, t}, & T_{1}<F R_{i, t-1} \leq T_{2} \\
\alpha_{i}^{2}+\beta F R_{i, t-1}+\epsilon_{i, t}, & F R_{i, t-1}>T_{2}\end{cases} \\
& \gamma_{i, t}= \begin{cases}\alpha_{i}^{0}+\beta^{0} F R_{i, t-1}+\epsilon_{i, t}, & F R_{i, t-1} \leq T_{1} \\
\alpha_{i}^{1}+\beta^{1} F R_{i, t-1}+\epsilon_{i, t}, & T_{1}<F R_{i, t-1} \leq T_{2} \\
\alpha_{i}^{2}+\beta^{2} F R_{i, t-1}+\epsilon_{i, t}, & F R_{i, t-1}>T_{2}\end{cases}
\end{aligned}
$$

